\title{
KAJIAN MODEL PEMBELAJARAN: PENDEKATAN COGNITIVE APPRENTICESHIP MODEL CASE BASED REASONING DALAM PEMBELAJARAN MATEMATIKA
}

\author{
Rina Oktaviyanthi \\ Universitas Serang Raya (UNSERA) \\ email : rinaokta1210@yahoo.com
}

\begin{abstract}
Abstrak. Penalaran adaptif dan pengambilan keputusan merupakan kemampuan yang menjadi bahasan pada perkembangan kognitif dan merupakan dua kemampuan penentu dalam proses pemecahan masalah. Untuk itu membelajarkan kedua kemampuan kognitif tersebut pada peserta didik merupakan tugas guru yang perlu diupayakan sedini dan sebaik mungkin. Dalam kajian ini, penulis memaparkan penggabungan pendekatan pembelajaran Cognitive Apprenticeship dengan model Case Based Reasoning yang akan dikembangkan sebagai salah satu upaya dalam mengoptimalkan dua kemampuan kognitif, penalaran adaptif dan pengambilan keputusan. Pendekatan Cognitive Apprenticeship memasilitasi peserta didik melalui pembelajaran bertahap dan menawarkan pengkondisian lingkungan belajar langsung pada ahlinya melalui kegiatan modeling, coaching, scaffolding, articulation, reflection dan exploration. Sementara Case Based Reasoning digunakan lebih khusus ketika peserta didik menyelesaikan masalah dengan siklus penyelesaian retrieve, reuse, revise dan retain. Kajian ini merupakan studi pendahuluan terkait implementasi pendekatan pembelajaran Cognitive Apprenticeship model Case Based Reasoning yang akan dilakukan penulis. Adapun tujuan dari kajian ini adalah (1) menguraikan pendekatan pembelajaran Cognitive Apprenticeship, (2) menjelaskan model Case Based Reasoning, dan (3) memaparkan pendekatan pembelajaran Cognitive Apprenticeship model Case Based Reasoning.
\end{abstract}

Kata kunci : case based reasoning, cognitive apprenticeship, kajian model, pengembangan model pembelajaran, penalaran adaptif, pengambilan keputusan

\section{PENDAHULUAN}

Belajar matematika merupakan proses kompleks yang dalam perkembangannya hingga saat ini para ahli pendidikan matematika melalui kajian dan penelitian terus mencari dan memperbaharui metode-metode yang efektif dan efisien tentang bagaimana membelajarkan matematika tanpa mengabaikan kondisi dan karakteristik peserta didik dan tanpa mengurangi esensi dari matematika itu sendiri. Telah menjadi keumuman bersama bahwa belajar matematika lebih dari sekedar pengetahuan keterampilan dan prosedur. Tujuan dari pembelajaran matematika jauh melampaui pembentukan keterampilan mekanik. Wacana penting mengenai peserta didik dalam pembelajaran matematika yaitu bagaimana mereka menjadi individu yang mahir matematika. Kemahiran matematika tidak hanya bermanfaat dalam proses pencapaian akademik peserta didik di pendidikan formal, melainkan salah satu aspek yang digunakan dalam memecahkan masalah di kehidupan nyata ketika peserta didik berinteraksi dengan lingkungan. Sullivan, P. (2011) menekankan pentingnya memahirkan peserta didik dengan matematika melalui pandangan dasar terhadap pendidikan matematika yaitu (1) functional yang memandang ilmu matematika dapat melengkapi kebutuhan peserta didik di masa depan, dan (2) specialist yang memandang ilmu matematika diperlukan bagi peserta didik yang akan mendalami matematika sebagai studi lanjut atau suatu profesi [1].

Namun untuk memahirkan matematika pada peserta didik bukan merupakan hal mudah. Dalam konteks penggunaan matematik dalam kehidupan nyata, fakta yang terungkap dari hasil penelitian bahwa peserta didik masih mengalami kesulitan untuk melihat bagaimana aljabar, geometri trigonometri, kalkulus atau materi matematika lainnya dapat membantu mereka dalam 
menyelesaikan masalah yang terkait dengan aspek kehidupan sehari-hari dan banyak aplikasi dari semuanya itu berada di luar jangkauan peserta didik [2][3]. Permasalahan guru di lapangan yang juga dialami oleh penulis adalah tentang bagaimana cara terbaik yang dapat ditempuh untuk membantu peserta didik menghadapi kesulitannya ketika belajar matematika, yang harapan akhirnya yaitu menjadikan peserta didik mahir dalam matematika baik secara teori maupun aplikasinya. Kemahiran matematika memiliki pengertian bahwa peserta didik dapat menggunakan ide, generalisasi, keterampilan yang diajarkan untuk menyelidiki, menganalisis, menjustifikasi suatu strategi dan situasi melalui proses mengajukan pertanyaan (questioning), menjelaskan alasan secara logis (explaining reasoning), membandingkan metode (comparing methods), dan memecahkan masalah (solving problems) baik untuk tujuan menyelesaikan masalah matematika atau digunakan dalam situasi kehidupan nyata [4]. Pemecahan masalah termasuk dalam cognitive concern, selain attention, memory, language, dan learning, yang dalam praktik pemahirannya memerlukan planning, reasoning, dan decision making [5][6]. Memokuskan pada kemampuan reasoning dan decision making, keduanya merupakan kemampuan kognitif tingkat tinggi yang masih menjadi tema penyelidikan dan penelitian secara intensif oleh pendidik, psikolog bahkan filsuf dalam kurun waktu tiga puluh tahun terakhir [7][8][9]. Dua kemampuan kognitif ini menjadi kemampuan penentu dalam proses pemecahan masalah. Untuk itu membelajarkan kedua kemampuan kognitif tersebut pada peserta didik merupakan tugas guru yang perlu diupayakan sedini dan sebaik mungkin serta sejalan dengan karakteristik pendidikan dan peserta didik itu sendiri.

Dalam hubungannya dengan proses memahirkan suatu kemampuan pada peserta didik, pengajaran dan pembelajaran yang dijalankan pada masa terdahulu dilakukan melalui apprenticeship yaitu proses individu belajar tahapan-tahapan memperoleh keterampilan dan keahlian mengenai sesuatu dari interaksi dengan pakar atau orang yang lebih ahli [10]. Pakar atau orang yang lebih ahli memiliki pengertian orang yang menguasai permasalahan yang dipelajari. Metode apprenticeship ini sudah dilakukan jauh sebelum pendidikan di sekolah bahkan universitas muncul dan dipandang sebagai salah satu metode pembelajaran yang efektif karena peserta didik belajar langsung di bawah pengawasan pakar atau orang yang lebih ahli atau yang lebih berpengalaman melalui pemberian dukungan dan contoh sehingga peserta didik atau orang yang kurang berpengalaman mencapai pengetahuan dan keterampilan baru [11][12]. Dalam perkembangannya pengajaran yang melibatkan proses abstrak, misalnya matematika, digunakan metode yang dinamakan Cognitive apprenticeship.

Dua kemampuan kognitif dalam studi ini, penalaran adaptif dan pengambilan keputusan, memiliki ketergantungan satu sama lain dalam kerangka pemecahan masalah. Pada proses pemecahan masalah, individu menggunakan pengetahuan dan penalaran untuk memutuskan apa yang harus dilakukan, menyimpulkan cara terbaik dalam mencapai tujuan dan menentukan konsekuensi dari keyakinan tindakan yang diambil [7][13]. Dalam praktiknya, salah satu komponen penting pendukung proses pemecahan masalah adalah dengan mengingat pengalaman sebelumnya pada situasi yang sama [14][15]. Pemikiran ini kemudian melahirkan suatu ide dalam metode penyelesaian masalah berdasarkan pengalaman yang dikenal dengan Case based reasoning. Ide dasar dari metode ini adalah memecahkan masalah baru dengan mengadaptasi solusi sukses yang telah digunakan sebelumnya pada masalah terdahulu melalui tahapan [16][17].

\section{COGNITIVE APPRENTICESHIP}

Apprenticeship merupakan metode pembelajaran masa lampau dimana seseorang belajar untuk mendapatkan keahlian atau kemahiran mengenai suatu ilmu atau keterampilan dengan melihat langsung proses kerja dari ahli atau orang yang lebih berpengalaman. Pada mulanya metode apprenticeship berfokus pada pengajaran umum seperti kerajinan yang dapat dilakukan dengan menggunakan tangan, dikenal dengan traditional apprenticesip. Dalam traditional apprenticeship seorang ahli menunjukkan bagaimana ia melakukan suatu pekerjaan, dan ini merupakan ide dasar dari apprenticeship. Ada empat aspek penting dari traditional 
apprenticeship yaitu modeling, coaching, scaffolding, dan fading. Sementara pengajaran yang melibatkan proses berpikir abstrak seperti membaca, menulis, atau matematika, Collins, A., Brown, J. S., \& Holum, A. (1991) menyarankan metode yang disebut dengan cognitive apprenticeship yang merupakan kerangka instruksional hasil dari sintesis antara pendidikan formal dan traditional apprenticeship yang bertujuan membuat proses berpikir dari kegiatan belajar lebih visible baik bagi guru maupun peserta didik [10].

Dalam proses pembelajaran dan pengajaran, cognitive apprenticeship menekankan pada tiga isu utama yaitu pertama metode ini ditujukan pada proses mengajar dimana seorang ahli berfungsi untuk menangani tugas-tugas yang kompleks dengan penerapan pengetahuan konseptual dan faktual sehingga semua aspek tugas atau masalah dapat terlihat (visible) oleh peserta didik yang selanjutnya dapat mendukung kemampuan penalaran adaptif dan pengambilan keputusan dalam proses menyelesaikan tugas atau memecahkan masalah. Kedua, cognitive apprenticeship mengacu pada pembelajaran pengalaman terbimbing pada ranah kognitif dan metakognitif, keterampilan dan proses. Ketiga, pentingnya menciptakan atau menyediakan berbagai situasi yang berbeda dan diberikan kompleksitas bertahap sehingga transfer ilmu ke situasi baru akan menjadi lebih memungkinkan dan selanjutnya dapat memberikan keterampilan beragam [18][19].

Kecenderungan menggunakan metode cognitive apprenticeship dilatarbelakangi oleh dua hal yaitu pertama belum berkembangnya kemampuan reasoning dan decision making dalam menentukan strategi memecahkan tugas-tugas kompleks atau masalah kehidupan nyata layaknya seorang ahli. Kedua, meskipun sistem pengorganisasian dan penyampaian pengetahuan konseptual dan faktual di sekolah telah relatif berhasil dan dipandang mengalami kemajuan, namun aspek student expertise masih sedikit mendapat perhatian. Dari dua masalah tersebut setidaknya dapat disimpulkan tiga dampak langsung yang dialami peserta didik yaitu (1) dalam memecahkan masalah matematika, peserta didik mengandalkan pengetahuannya berdasarkan pola standar buku yang digunakan dalam melihat representasi suatu masalah, bukan pada pengetahuan mereka mengenai strategi pemecahan masalah atau sifat intrinsik dari masalah itu sendiri, (2) peserta didik mengalami kebingungan untuk menyelesaikan suatu masalah ketika dihadapkan pada masalah yang berada di luar pola standar buku, dan (3) peserta didik tidak mampu mengoptimalkan penggunaan sumber-sumber yang tersedia untuk meningkatkan keterampilan mereka dikarenakan tidak memiliki acuan atau model bagaimana memanfaatkan sumber-sumber tersebut.

Secara utuh, ada empat prinsip dalam merancang lingkungan cognitive apprenticeship, yaitu (1) content: domain knowledge, heuristic strategies, control strategies, learning strategies; (2) method: modeling, coaching, scaffolding, articulation, explorations; (3) sequencing: global before local skills, increasing complexcity, increasing diversity; dan (4) sociology/ context: situated learning, community of practice, intrinsic motivation, cooperation.

Pada proses pelaksanaannya, cognitive apprenticeship mencakup enam langkah utama pembelajaran, yaitu:

1. Modeling, melibatkan ahli dalam menunjukkan dan menjelaskan cara mereka berpikir dan menyelesaikan tugas atau memecahkan masalah sehingga peserta didik dapat mengamati, memahami dan membangun proses konseptual model yang diperlukan menyelesaikan tugas.

2. Coaching, ahli membina peserta didik melalui berbagai kegiatan seperti memilih tugas, mengarahkan petunjuk dan tahapan bantuan (scaffolding), mengevaluasi kegiatan dan mendiagnosis jenis masalah yang dihadapi, menyediakan tantangan, menawarkan dorongan, dan memberikan umpan balik. Intinya adalah proses mengawasi belajar peserta didik. Sementara peserta didik berlatih melaksanakan tugas dengan konseptual metode yang dibangunnya.

3. Scaffolding, dukungan ahli pada peserta didik dalam melaksanakan tugas atau menyelesaikan masalah melalui peningkatan kompleksitas masalah dan mengurangi tingkat 
bantuan (fading) sesuai dengan kemajuan peserta didik, ahli membantu peserta didik berturut-turut mendekati tujuan yaitu menyelesaikan tugas secara independen.

4. Articulation, peserta didik diberikan kesempatan untuk mengartikulasikan proses pengetahuan, penalaran atau pemecahan masalah dan memperjelas cara berpikir mereka sendiri.

5. Reflection, peserta didik membandingkan pikiran mereka pada ahli atau dengan peserta didik lain.

6. Exploring, peserta didik memanipulasi dan mengeksplorasi keterampilan atau pengetahuan yang dipelajari untuk mempromosikan pemahaman mereka yang sebenarnya.

\section{CASE BASED REASONING}

Case based reasoning (CBR) pada mulanya merupakan bidang penelitian di bidang kecerdasan buatan (Artificial Intelligence) yang melibatkan penyelidikan dasar teoritis, pengembangan sistem, dan membangun aplikasi praktis dari pemecahan masalah berdasarkan pengalaman. Ada beberapa perbedaan mendasar CBR dengan AI yaitu (1) dalam metode ini masalah baru diselesaikan dengan mencari kasus lama yang memiliki kesamaan karena CBR mampu memanfaatkan pengetahuan spesifik yang dialami sebelumnya, dan (2) CBR merupakan pendekatan bertahap dan belajar berkelanjutan karena setiap pengalaman baru akan disimpan setiap kali masalah telah dipecahkan dan dapat dibuka kembali untuk menyelesaikan masalah di masa mendatang. Prinsip yang mendasari CBR adalah memecahkan masalah baru dengan mengadaptasi solusi yang telah digunakan untuk menyelesaikan masalah di masa lalu [16][17]. Case based reasoning adalah metode penalaran analogis yang menyediakan metode untuk menyelesaikan masalah dan model kognitif individu dengan berfokus pada pengalaman sebelumnya. Pengalaman sebelumnya dapat memainkan beberapa peran, diantaranya yaitu (1) merekomendasikan solusi untuk masalah baru atau cara dalam menafsirkan situasi, (2) sebagai penanda masalah yang akan muncul, dan (3) mempertimbangkan efek potensial dari solusi yang diusulkan untuk diprediksi [17][20]. Hasil penelitian Tawfik, A. A. \& Keene, C. W. (2013) menunjukkan bahwa peserta didik mengalami kesulitan dalam menyelesaikan tugas dengan transisi masalah pada masalah yang tidak terstruktur (ill-structured problem) dan merekomendasikan CBR untuk memasilitasi transisi masalah ini. Peneliti kognitif modern mencatat pentingnya memecahkan masalah yang tidak terstruktur untuk memunculkan dan mengembangkan keterampilan berpikir yang lebih tinggi seperti penalaran, argumentasi, dan evaluasi [15][21].

Dalam terminologi CBR, kasus (case) biasanya menunjukkan situasi masalah. Sebuah situasi masalah yang pernah dialami sebelumnya, yang telah digambarkan dan dipelajari dengan cara yang dapat digunakan kembali dalam penyelesaian masalah di masa mendatang disebut kasus lama, kasus sebelumnya, kasus yang disimpan, atau kasus yang dipertahankan. CBR berbasis pada memori sehingga mencerminkan penggunaan ingatan individu terhadap suatu masalah dan solusinya sebagai titik awal dalam pemecahan masalah baru. Memori ini menjadi kunci dari penggunaan CBR yang dapat mengakses pengalaman yang benar pada saat dibutuhkan. Pemecahan masalah dengan menggunakan CBR melibatkan pemerolehan deskripsi suatu masalah, mengukur kesamaan masalah yang dihadapi pada masalah sebelumnya yang telah disimpan dalam memori dengan solusi yang telah dikenal, mengambil satu atau lebih kasus yang mirip, dan mencoba menggunakan kembali solusi dari kasus yang diambil. Solusi yang diajukan sistem kemudian dievaluasi dan direvisi yang selanjutnya dipertahankan sebagai kasus baru dan sistem telah belajar memecahkan masalah baru. Belajar dengan CBR terjadi secara natural dengan produk akhirnya yaitu pemecahan masalah. Ketika suatu masalah berhasil diselesaikan, pengalaman keberhasilan penyelesaian itu akan dipertahankan untuk digunakan dalam pemecahan masalah di masa mendatang. Ketika upaya untuk memecahkan masalah gagal, alasan kegagalan diidentifikasi dan diingat untuk menghindari kesalahan yang sama. CBR mendukung pembelajaran berbasis pengalaman seperti yang dinyatakan Aamodt, A. \& Plaza, E. (1994) yaitu, "Case-based reasoning favours learning from experience, since it is 
usually easier to learn by retaining a concrete problem solving experience than to generalize from it [22]." Namun pembelajaran yang efektif di CBR membutuhkan seperangkat metode bekerja yang baik untuk mengekstrak pengetahuan yang relevan dari pengalaman, mengintegrasikan kasus pada struktur pengetahuan yang ada, dan menandai kasus yang dihadapi saat ini untuk diingat kembali pada kasus serupa di masa mendatang [23][24][25].

Siklus CBR pertama kali diusulkan oleh Aamodt, A. \& Plaza, E. (1994) yang terdiri atas empat langkah berurutan dimulai dengan (1) retrieve, mengambil kasus yang serupa; (2) reuse, menggunakan kembali informasi dan pengetahuan dari kasus sebelumnya untuk menyelesaikan masalah pada kasus yang dihadapi; (3) revise, memperbaiki solusi yang diusulkan; dan (4) retain, mengingat pengalaman penyelesaian kasus yang mungkin dapat berguna untuk memecahkan masalah masa mendatang [22]. Sebuah kasus terdiri atas tiga unsur yaitu deskripsi masalah, solusi yang diterapkan dan hasil yang diperoleh. Himpunan kasus diatur dalam case memory (CM). Karena CBR merupakan proses pencarian dan pencocokan kasus, maka representasi, pengindeksan dan penyimpanan kasus harus efektif dan efisien.

1. Retrieve

Masalah yang sedang dihadapi dianalisis dan situasi fitur yang relevan digunakan mencari CM melalui indeks untuk menemukan satu kasus yang serupa. Kasus yang diambil kemudian diuji dengan tujuan pemilihan yang paling sesuai.

2. Reuse

Setelah satu kasus dipilih, individu harus mengadaptasikan kasus tersebut agar sesuai dengan karakteristik situasi yang dihadapi saat ini. Terdapat dua jenis adaptasi di CBR yaitu adaptasi terstruktur dimana aturan adaptasi diterapkan langsung pada solusi yang diambil, dan adaptasi derivatif yang menghasilkan solusi baru dengan menggunakan kembali metode solusi yang dihasilkan untuk kasus yang diambil. Adaptif solusi diterapkan pada masalah dalam domain nyata.

3. Revise

Setelah menerapkan solusi, tahap CBR berikutnya terdiri dari revisi hasil yang diperoleh untuk memeriksa apakah solusi yang diusulkan benar-benar dapat memecahkan masalah atau tidak. Jika solusi tidak berhasil, kegagalan dijelaskan dan solusinya diperbaiki. Oleh karena itu, ada dua peluang untuk belajar bergantung pada evaluasi hasil:

(a) Ketika masalah berhasil diselesaikan, data pengalaman yang digunakan dalam tahap berikutnya membentuk sebuah kasus baru (belajar dari kesuksesan).

(b) Ketika solusi gagal, alasan kegagalan diidentifikasi, dijelaskan dan diperbaiki. Kegagalan dan perbaikan digunakan dalam tahap retain untuk membentuk kasus baru (belajar dari kegagalan).

4. Retain

Pada tahap ini, masalah yang sedang dihadapi, solusi yang diusulkan dan hasilnya disimpan dalam CM. Kasus baru dibuat mengekstrasi beberapa data dari pengalaman baru, seperti fitur yang relevan, solusi dan hasil yang diterapkan. Jika solusi itu berhasil, maka kasus baru disimpan untuk membantu dalam kegiatan pemecahan masalah yang akan datang. Jika solusi gagal, maka kasus disimpan dalam CM bersama dengan kegagalan dan perbaikan dalam rangka menghindari kegagalan serupa. Kasus yang baru harus diintegrasikan ke dalam CM dan indeks diperbaharui. 


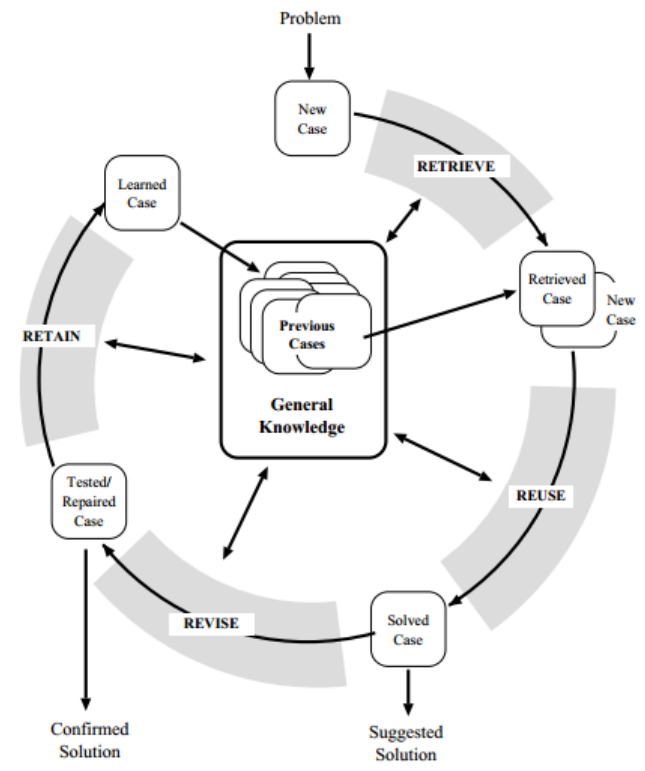

Gambar 1. Bagan Siklus Case Based Reasoning Aamodt, A. \& Plaza, E. [22]

\section{PROSES PELAKSANAAN PEMBELAJARAN}

Adapun proses pelaksanaan pembelajaran dengan menggunakan pendekatan Cognitive apprenticeship model Case based reasoning adalah sebagai berikut:

Tabel 1. Proses Pelaksanaan Pembelajaran Cognitive Apprenticeship-Case Based Reasoning

\begin{tabular}{|c|c|c|}
\hline $\begin{array}{l}\text { Langkah } \\
\text { Kegiatan }\end{array}$ & Aktivitas Guru & Aktivitas Peserta Didik \\
\hline Modeling & $\begin{array}{l}\text { - Guru sebagai ahli menunjukkan dan } \\
\text { menjelaskan kegiatan menyelesaikan } \\
\text { tugas atau memecahkan masalah } \\
\text { - Guru menggunakan langkah berurutan } \\
\text { case based reasoning dalam } \\
\text { menyelesaikan tugas atau memecahkan } \\
\text { masalah, yaitu: } \\
\text { a. Retrieve (mengambil kasus serupa) } \\
\text { b. Reuse (menggunakan kembali } \\
\text { informasi dari kasus sebelumnya) } \\
\text { c. Revise (memperbaiki solusi yang } \\
\text { diusulkan) } \\
\text { d. Retain (mengingat pengalaman kasus } \\
\text { sebelumnya untuk memecahkan kasus } \\
\text { yang akan datang) }\end{array}$ & $\begin{array}{ll}\text { - } & \text { Peserta didik mengamati dan } \\
\text { mencermati setiap proses yang } \\
\text { dilakukan guru dalam } \\
\text { menyelesaikan tugas atau } \\
\text { memecahkan masalah } \\
\text { - } \\
\text { Peserta didik membangun proses } \\
\text { konseptual model dan metode dari } \\
\text { hasil pengamatan } \\
\text { - } \\
\text { Peserta didik memahami langkah } \\
\text { penyelesaian masalah dengan case } \\
\text { based reasoning }\end{array}$ \\
\hline Coaching & $\begin{array}{ll}- & \text { Guru membina peserta didik melalui } \\
\text { - } & \text { kegiatan memilih tugas } \\
& \text { Guru mengarahkan petunjuk dan tahapan } \\
\text { bantuan (scaffolding) } \\
\text { - } & \text { Guru mengevaluasi kegiatan dan } \\
\text { mendiagnosis jenis masalah yang dihadapi } \\
\text { - } & \text { Guru menyediakan tantangan } \\
- & \text { Guru memasilitasi dan memberikan } \\
\text { umpan balik }\end{array}$ & 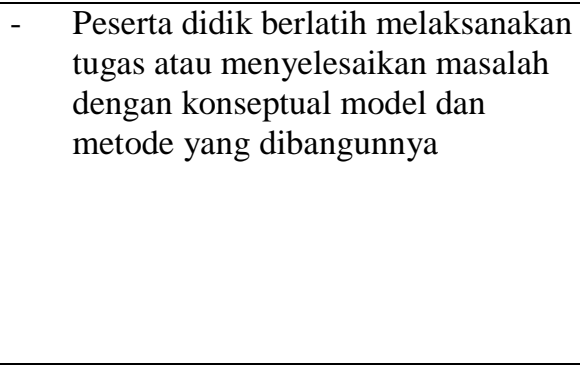 \\
\hline Scaffolding & $\begin{array}{ll}- & \text { Guru meningkatkan kompleksitas tugas } \\
& \text { atau masalah } \\
\text { - } & \text { Guru mengurangi tingkat bantuan (fading) } \\
& \text { sesuai dengan kemajuan peserta didik } \\
\text { - } & \text { Guru membantu peserta didik sampai } \\
\end{array}$ & $\begin{array}{ll}\text { - } & \text { Peserta didik menyelesaikan tugas } \\
\text { dengan kompleksitas bertahap } \\
\text { - } \\
\text { Peserta didik memecahkan masalah } \\
\text { dengan tingkat bantuan yang } \\
\text { berkurang }\end{array}$ \\
\hline
\end{tabular}




\begin{tabular}{|c|c|c|}
\hline & $\begin{array}{l}\text { peserta didik dapat mengerjakan tugas } \\
\text { atau masalah secara mandiri }\end{array}$ & $\begin{array}{ll}\text { - } & \text { Peserta didik mengerjakan tugas } \\
\text { secara mandiri }\end{array}$ \\
\hline Articulation & $\begin{array}{l}\text { - Guru memberikan kesempatan peserta } \\
\text { didik mengartikulasikan proses } \\
\text { pengetahuan yang diperolehnya } \\
\text { - Guru mendorong peserta didik untuk } \\
\text { memverbalkan ide, pemikiran, } \\
\text { pengetahuan, dan pemahaman yang } \\
\text { dibangunnya }\end{array}$ & $\begin{array}{l}\text { Peserta didik mengartikulasikan } \\
\text { pengetahuan, penalaran, } \\
\text { memperjelas ide, pemikiran, dan } \\
\text { pemahamannya melalui komunikasi } \\
\text { dengan guru atau teman sekelompok } \\
\text { dengan berdiskusi atau } \\
\text { menyampaikannya lisan di depan } \\
\text { kelas }\end{array}$ \\
\hline Reflection & $\begin{array}{l}\text { - } \quad \text { Guru memasilitasi peserta didik untuk } \\
\text { melakukan perbandingan hasil } \\
\text { pemahaman dan pemikiran peserta didik } \\
\text { baik dengan guru sendiri atau dengan } \\
\text { peserta didik lain } \\
\text { - } \quad \text { Guru menyediakan waktu berdiskusi }\end{array}$ & 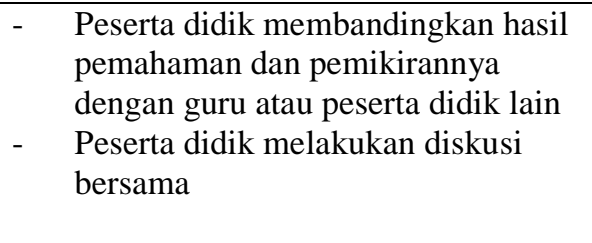 \\
\hline Exploring & 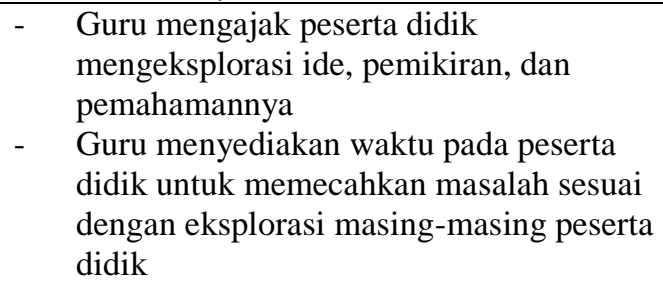 & 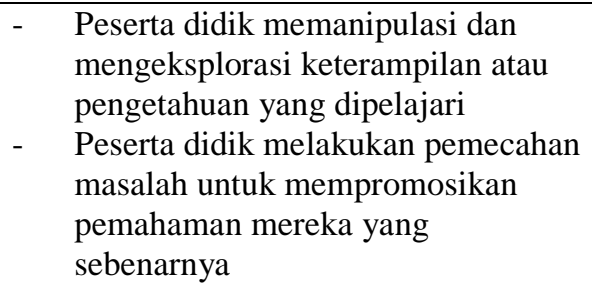 \\
\hline
\end{tabular}

\section{KESIMPULAN}

Penalaran dan pengambilan keputusan merupakan kemampuan pada ranah kognitif yang pengoptimalan fungsi dan penggunaannya dapat memberikan luaran yang baik pada individu karena menyediakan kerangka kerja untuk mengatur strategi yang efektif dalam menentukan pilihan pada proses penyelesaian masalah yang berhubungan dengan matematika dan masalah kehidupan secara umum serta keyakinan pada kemampuan diri sendiri. Dua kemampuan kognitif dan satu kemampuan afektif ini menjadi penting ditanamkan dan ditumbuhkembangkan pada peserta didik dengan harapan mereka menjadi mahir, selalu berpikir dan mempertimbangkan setiap pilihan yang tersedia beserta konsekuensinya sebelum melakukan tindakan, dan peserta didik dapat mengontrol perilaku impulsif sehingga dapat membuat keputusan yang lebih baik dan rasional dalam menentukan tujuan, bertahan, dan melihat diri sendiri sebagai individu yang mampu untuk berhasil mencapai tujuan.

Pendekatan Cognitive apprenticeship dengan model Case based reasoning dikembangkan sebagai salah satu upaya dalam mengoptimalkan kemampuan kognitif dan afektif yang berperan penting dalam proses pemecahan masalah. Menggabungkan pendekatan Cognitive apprenticeship dengan model Case based reasoning memberikan langkah pengajaran bertahap dan menawarkan pengkondisian lingkungan belajar langsung pada ahlinya melalui kegiatan modeling, coaching, scaffolding, articulation, reflection dan exploration dengan proses menyelesaikan masalah yang lebih dikhususkan pada pengalaman menyelesaikan masalah terdahulu yang diimplementasikan pada masalah yang dihadapi saat ini melalui siklus penyelesaian retrieve, reuse, revise dan retain. Dengan menggunakan langkah pengajaran bertahap dan proses menyelesaikan masalah berdasarkan pengalaman dapat memberikan peserta didik kesempatan untuk membangun pengetahuan dan pemahaman serta mengoptimalkan kemampuan penalaran adaptif dan pengambilan keputusan untuk diimplementasikan dan diberdayagunakan dalam menyelesaikan tugas atau pemecahan masalah di kehidupan keseharian peserta didik.

\section{DAFTAR PUSTAKA}

[1] Sullivan, P. (2011). Teaching Mathematics: Using Research-Informed Strategis. Australia: ACER Press. 
[2] Legner, P. (2013). The Value of Teaching Mathematics. UK: Mathigon, National STEM Centre. [Online] Tersedia: http://mathigon.org/resources/value-of-mathematics.pdf [Diakses 05 April 2015].

[3] Yeo, J. B. W. (2010). Why study mathematics? Applications of mathematics in our daily life. Dalam B. Kaur \& J. Dindyal (Eds.), Mathematical modelling and applications: Association of Mathematics Educators 2010 Yearbook (PP. 151-177). Singapore: World Scientific.

[Online]

Tersedia: http://math.nie.edu.sg/bwjyeo/publication/AMEYearbook2010 RealLifeApplications.pdf [Diakses 05 April 2015].

[4] Groves, S. (2012). Developing Mathematical Proficiency. Journal of Science and Mathematics Education in Southeast Asia, Volume 35, No. 2, pp. 119-145.

[5] Bruer, J. T. (2006). Points of View: On the Implications of Neuroscience Research for Science Teaching and Learning: Are There Any? Life Science Education, Volume 5, Summer 2006, pp. 104-110. [Online] Tersedia: http://www.uni.edu/gabriele/page4/files/bruer-the-primacy-of-psychology-in-the-science-oflearning.pdf [Diakses 01 April 2015].

[6] Neumann, D. \& Lequerica, A. (2009). Cognitive Problems after Traumatic Brain Injury. US: University of Washington. [Online] Tersedia: http://uwmsktc.washington.edu/TBI cognitive.pdf [Diakses 01 April 2015].

[7] Johnson-Laird, P. N., \& Shafir, E. (1993). The Interaction between Reasoning and Decision Making: An Introduction. Cognition, Volume 49 (1993), pp. 1-9.

[8] Evans, J. St. B. T. (2008). Dual-Processing Accounts of Reasoning, Judgement and Social Cognition. UK: University of Plymouth.

[9] Galotti, K. M. (2010). Cognitive Development: Infancy through Adolescence. Thousand Oaks, CA: Sage.

[10] Collins, A., Brown, J. S., \& Holum, A. (1991). Cognitive Apprenticeship: Making Thinking Visible. The Quartely Journal of The American Foundation of Teachers, Winter 1991, Issue American Educator.

[11] Dennen, V. P. (2004). Cognitive Apprenticeship in Educational Practice: Research on Scaffolding, Modeling, Mentoring, and Coaching as Instructional Strategies. Dalam D. H. Jonassen (Ed.), Handbook of Research on Educational Communications and Technology (2nd ed., pp. 813-828). Mahwah, NJ: Lawrence Erlbaum Associates. [Online] Tersedia: http://ocw.metu.edu.tr/pluginfile.php/9106/mod resource/content/1/dennen.pdf [Diakses 15 Maret 2015].

[12] Vikberg, T. (2012). Teaching an Introductory Course in Logic to Undergraduate Students Using Extreme Apprenticeship Method. Helsinki: University of Helsinki.

[13] Azuma, R., Daily, M., \& Furmanski, C. (2006). A Review of Time Critical Decision Making Models and Human Cognitive Processes. [Online] Tersedia: http://ronaldazuma.com/papers/aerospace06_final.pdf [Diakses 05 April 2015].

[14] Newell, B. R. (2008). Cognitive Processes, Models and Metaphors in Decision Research. Judgment and Decision Making, Volume 3, No. 3, March 2008, pp. 195-204.

[15] Tawfik, A. A. \& Keene, C. W. (2013). Applying Case-Based Reasoning Theory to Support Problem-Based Learning. The Journal of Applied Instructional Design, Volume 3, Issue 2, pp. 31-40.

[16] Kolodner, J. L. \& Guzdial, M. (1999). Theory and Practice of Case-Based Learning Aids. Dalam D.H. Jonassen \& S. M. Land (Eds.), Theoretical Foundations of Learning Environments, Lawrence Erlbaum Associates: Mahwah, NJ, pp. 215-242. [Online] Tersedia: www.cs.auckland.ac.nz/ ian/CBR/kolodner.pdf [Diakses 01 April 2015].

[17] Kolodner, J. L. (2004). Instructional Design: Case-Based Reasoning. Dalam Goldman, S. (Ed.), Encyclopedia of Education. Lawrence Erlbaum Associates: Mahwah, NJ. [Online] Tersedia: http://www.cc.gatech.edu/projects/lbd/pdfs/instdesign.pdf [Diakses 02 April 2015]. 
[18] Schunn, C. D. \& Silk, E. M. (2011). Learning Theories for Engineering and Technology Education. Dalam Barak, M. \& Hacker, M. (eds.), Fostering Human Development through Engineering and Technology Education, pp. 3-18. Sense Publisher.

[19] Kuhn, G. (2011). Cognitive Apprenticeship. US: Wayne State University.

[20] Salem, A. B. M. \& Katoua, H. (2013). Case-Based Reasoning Approach for Intelligent Tutoring Systems. Recent Techniquesin Educational Science, Proceedings of the 1st International Conference on Computer Supported Education (COSUE '13), Vouliagmeni, Athens, Greece, May 14-16, 2013, pp. 21-26, http://www.wseas.us/elibrary/conferences/2013/Vouliagmeni/CCC/CCC-02.pdf [Diakses 01 April 2015].

[21] Cevik, Y. D. (2011). Examining Preservice Teachers' Reasoning and Decision Making in Three Case-Based Approaches. US: Iowa State University.

[22] Aamodt, A. \& Plaza, E. (1994). Case-Based Reasoning: Foundational Issues, Methodological Variations, and System Approaches. Al Communications, IOS Press, Volume 7, No. 1, pp. 39-59.

[23] Main, J., Dillon, T. \& Shiu, S. (2001). A Tutorial on Case-Based Reasoning. Dalam Pal, S.K., Dillon, T. S., \& Yeung, D. S. (Eds.), Soft Computing in Case Based Reasoning (pp. 1-28). London, UK: Springer. [Online] Tersedia: http://www4.comp.polyu.edu.hk/ csckshiu/pdf/shiu01scbrb2.pdf $\quad$ Diakses 01 April 2015].

[24] Poeppelmann, D. (2011). A Refined Case-Based Reasoning Approach to Academic Capacity Planning. Jerman: University of Osnabrueck. http://subs.emis.de/LNI/Proceedings/Proceedings182/395.pdf [Diakses 04 April 2015].

[25] Taan, V. \& Kou, X. (2014). Case-based Reasoning to Help Educators Design with Web 2.0. Educational Media International, Volume 51, No. 2, pp. 91-108. 